\title{
PENGARUH CORPORATE SOCIAL RESPONSIBILITY BERBASISKAN KARAKTERISTIK SOCIAL BANK TERHADAP KINERJA PERUSAHAAN PERBANKAN DI BURSA EFEK INDONESIA
}

\author{
Yohanes Andri Putranto dan Suramaya Suci Kewal \\ Sekolah Tinggi Ilmi Ekonomi (STIE) Musi Palembang \\ Email: but3k77@gmail.com suramayasuci@gmail.com
}

\begin{abstract}
The purpose of this study is to test empirically the effect of Corporate Social Responsibility (CSR) on the financial performance of banking companies listed in the Indonesia Stock Exchange (IDX). In contrast to previous studies, this study uses the social bank characteristics for the measurement of CSR. Social bank characteristics are a proxy of sustainability development. The company's performance is proxied by Tobin's Q. The sample was banking companies listed on the IDX in 2008 to 2012. This study used a multiple regression model and the R software to test the hypothesis. At the $5 \%$ significance level, the results show that CSR significantly affects the financial performance of banking companies listed in the IDX. The regression coefficient of CSR on corporate performance is -0.075769 , thus CSR as measured by the social bank characteristics as a proxy of sustainability development is significantly negative on firm financial performance as measured by Tobin's Q. In other words, CSR-based sustainability development does not affect the increase of financial performance of banking companies that are listed in the IDX.
\end{abstract}

Key words: Corporate Social Responsibility, sustainability development, financial performance, social bank,

Abstrak: Tujuan penelitian ini adalah untuk menguji secara empiris pengaruh Corporate Social Responsibility (CSR) terhadap kinerja perusahaan-perusahaan perbankan yang terdaftar di Bursa Efek Indonesia. Berbeda dengan penelitianpenelitian sebelumnya, dalam penelitian ini variabel CSR diukur dengan menggunakan karakteristik social bank. Penggunaan karakteristik social bank dimaksudkan agar mendapatkan ukuran variabel CSR yang sungguh-sungguh bertujuan untuk sustainability development. Untuk kinerja perusahaan dalam penelitian ini diproksikan dengan Tobin's Q. Sampel penelitian ini adalah perusahaan perbankan yang terdaftar secara berturut-turut dari tahun 2008 sampai dengan 2012. Penelitian ini menggunakan model regresi berganda dan memakai software $\mathrm{R}$ untuk menguji hipotesis. Hasil pengujian hipotesis pada tingkat signifikansi 5\% menunjukkan bahwa Corporate Social Responsibility (CSR) berpengaruh terhadap kinerja perusahaan-perusahaan perbankan yang terdaftar di Bursa Efek Indonesia. Koefisien pengaruh CSR terhadap kinerja perusahaan adalah -0,075769, dengan demikian dapat dinyatakan bahwa dalam penelitian ini CSR yang diukur dengan pendekatan karakteristik social bank sebagai proksi sustainability development berpengaruh negatif secara signifikan terhadap kinerja perusahaan yang diukur dengan Tobin's Q. Atau dengan kata lain dapat dinyatakan bahwa CSR yang berbasis sustainability development tidak mempengaruhi peningkatan kinerja perusahaan perbankan yang terdaftar di BEI.

Kata kunci: Corporate Social Responsibility, sustainability development, kinerja perusahaan, social bank, 


\section{PENDAHULUAN}

Citra perusahaan merupakan salah satu bentuk penilaian masyarakat terhadap perusahaan tersebut. Jika citra perusahaan buruk yang dimunculkan di media maka akan menghambat kelancaran operasional dan menghambat upaya peningkatan produktivitas dan profitabilitas (keuntungan) perusahaan, sehingga perusahaan sebagai pelaku bisnis tidak dapat menutup mata terhadap situasi dan kondisi di tempat perusahaan tersebut berada. Salah satu cara membentuk citra yang baik di mata masyarakat adalah dengan menerapkan CSR (Corporate Social Responsibility).

CSR (Corporate Social Responsibility) dipandang sebagai sebuah keharusan bagi suatu perusahaan. CSR bukan hanya sebagai tanggung jawab perusahaan, tetapi sudah menjadi kewajiban perusahaan. CSR adalah suatu peran bisnis dan harus menjadi bagian dari kebijakan bisnis. Oleh karena itu, bisnis tidak hanya mengurus masalah laba, tetapi juga sebagai sebuah institusi pembelajaran.

Pemerintah Indonesia menerbitkan peraturan No.47 Tahun 2012 mengenai Tanggung Jawab Sosial dan Lingkungan (CSR) yang didalamnya tertera secara tegas kewajiban dari segala jenis perusahaan untuk menyertakan pelaporan CSR dalam laporan RUPS masing-masing. Peraturan pemerintah ini dalam rangka melaksanakan ketentuan Pasal 74 Undang-Undang No. 40 Tahun 2007 tentang Perseroan Terbatas. Dalam peraturan pemerintah ini diatur mengenai tanggung jawab sosial dan lingkungan yang bertujuan mewujudkan pembangunan ekonomi berkelanjutan guna meningkatkan kualitas kehidupan dan lingkungan yang bermanfaat bagi komunitas setempat dan masyarakat pada umumnya maupun Perseroan itu sendiri dalam rangka terjalinnya hubungan Perseroan yang serasi, seimbang, dan sesuai dengan lingkungan, nilai, norma, dan budaya setempat. Dalam peraturan pemerintah ini, perseroan yang kegiatan usahanya di bidang dan/atau berkaitan dengan sumber daya alam diwajibkan untuk melaksanakan tanggung jawab sosial dan lingkungan. Kegiatan dalam memenuhi kewajiban tanggung jawab sosial dan lingkungan tersebut harus dianggarkan dan diperhitungkan sebagai biaya perseroan yang dilaksanakan dengan memperhatikan kepatutan dan kewajaran.

Pelaksanaan program CSR tidak hanya merupakan tanggung jawab perusahaan yang bersentuhan langsung dengan Sumber Daya Alam (SDA), perbankan juga merupakan salah satu sektor yang mempunyai tanggung jawab di bidang itu. Sebagai lembaga intermediasi untuk menerima dan menyalurkan kembali dana masyarakat, bank juga memiliki tanggung jawab etis, sosial, dan tanggung jawab discretionary, yaitu tanggung jawab yang semestinya tidak harus dilakukan tetapi dilakukan atas kemauan sendiri. Perbankan perlu melakukan pengungkapan CSR, namun pada kenyataannya masih banyak bank yang belum melaksanakan praktik CSR dengan benar dan mendalam. Pengungkapan CSR biasanya juga dilaporkan dengan sangat singkat, tidak berimbang, dan tidak melaporkan isu-isu yang material. Hal tersebut dikarenakan oleh masih banyak perusahaan yang belum mengerti bagaimana menciptakan program atau produk yang mampu membantu mengatasi permasalahan yang ada di masyarakat.

Penelitian ini fokus pada perusahan perbankan. Hal ini dikarenakan perusahaan perbankan memiliki aktivitas bisnis yang sedikit berbeda dibandingkan perusahaan sektor lain. Perusahaan perbankan memiliki proses bisnis yang tidak berdampak langsung terhadap sosial dan lingkungan. Tetapi di sisi lain, perusahaan perbankan memiliki dampak tidak langsung pada sosial dan lingkungan melalui proyek keuangan mereka, hal ini mendorong perusahaan perbankan dituntut harus melakukan CSR. 
Tujuan utama CSR adalah sustainability development. Tujuan ini akan tercapai jika CSR tercermin dalam proses bisnis suatu perusahaan. Dengan kata lain proses bisnis suatu perusahaan harus memberikan kontribusi positif yang signifikan terhadap pelestarian kualitas sosial dan lingkungan. CSR tidak boleh dipandang sebagai aktivitas yang terpisah dari proses bisnis suatu perusahaan. CSR tidak memberikan kontribusi signifikan bagi sustainability development dikarenakan penerapan CSR tidak diinternalisasi ke dalam core business perusahaan (Walker, 2010). Sustainable finance atau bisnis keuangan yang bertanggung jawab merupakan tuntutan utama yang ditujukan pada perusahaan perbankan terkait dengan sustainability development (Durbin, Herz, Hunter, \& Peck, 2006). Sustainable finance artinya proyek-proyek keuangan perusahaan perbankan mempertimbangkan aspek sosial, lingkungan, dan etika.

Sejak tahun 2000 perusahaan perbankan menggunakan dua instrumen CSR yang digunakan perusahaan perbankan untuk memenuhi tujuan sustainability development yaitu The Equator Principles dan Socialy Responsible Invesment (SRI). Namun dalam praktikknya kedua instrumen tersebut mendapat banyak kritik dan dianggap gagal untuk mencapai tujuan sustainability development serta cenderung dipakai perusahaan perbankan untuk melakukan greenwashing (Relaño, 2011). Sejak tahun 1980-an telah muncul institusi perbankan yang core business-nya mengutamakan sustainability development. Institusi ini disebut social bank atau ethical bank. Social bank merupakan contoh nyata institusi perbankan yang menjalankan sustainability finance. Institusi ini mengukur profitabilitas tidak hanya dari keuntungan finansial tapi juga mengutamakan manfaat sosial yang diperoleh. Social bank sangat berbeda dengan institusi perbankan umumnya. Social bank mengintegrasikan sustainability development ke dalam aktivitas bisnisnya yang sangat bertolak belakang dengan institusi perbankan umumnya yang memanfaatkan instrumen-instrumen sustainability development sebagai aksesoris untuk kepentingan strategi pemasaran. Social bank berani hanya mendapatkan profit yang kecil selama hal itu memberikan manfaat yang besar pada sosial dan lingkungan.

Relaño (2011) mengkarakteristikan social bank berdasarkan aktivitas bisnisnya ke dalam dua dimensi, yaitu dimensi eksternal dan internal. Pada dimensi eksternal, social bank menolak berpartisipasi dalam aktivitas spekulasi di pasar modal, investasi pada produk keuangan di pasar modal miliki sampai jatuh tempo, berfokus pada aktivitas original perbankan yaitu mengumpulkan simpanan dan mendistribusikan kredit, mengutamakan dimensi sosial, lingkungan, dan etika dalam proyek keuangannya, solidaritas dikembangkan antara penabung dengan peminjam untuk memungkinkan terciptanya pinjaman dengan bunga yang rendah untuk proyek yang bermanfaat bagi sosial dan lingkungan, karena kebijakan pinjaman social bank berisiko lebih tinggi dari bank umumnya maka jangkauan pelayanannya hanya lokal atau regional saja sehingga mereka dapat mengenal dengan baik wilayah dan orang-orang yang mereka danai. Dan dilihat dari dimensi internal, social bank cenderung memiliki sedikit kantor-kantor pelayanan dan lebih banyak beroperasi melalui telepon dan email, transparansi dalam melaporkan detail informasi aktivitas bisnisnya, partisipasi dan demokrasi dalam pengambilan keputusan, dan menjunjung tinggi kesetaraan martabat manusia.

Perusahaan yang melakukan CSR artinya ikut memperhatikan kepentingankepentingan stakeholders dari perspektif strategis. Pihak-pihak termasuk stakeholders dalam perusahaan perbankan antara lain adalah : manajer, nasabah, karyawan, pemerintah, dan pemegang saham. Sebagai akibatnya, stakeholder juga akan menaruh perhatian lebih terhadap kepentingan perusahaan dan tidak menutup kemungkinan hal tersebut dapat 
mendorong stakeholders untuk berinvestasi lebih ke perusahaan yang bersangkutan. Faktor ini akan membantu perusahaan untuk membangun kerja sama yang baik antara stakeholders dengan perusahaan (Duke II \& Kankpang, 2013). Beberapa penulis juga mengedepankan pentingnya reputasi CSR dalam rangka meningkatkan profitabilitasnya dalam jangka panjang (Davis, 1973 dalam Chen \& Wang, 2011).

Motivasi yang mendasari penelitian ini adalah masih sedikit hasil penelitian empiris mengenai pengaruh CSR terhadap kinerja keuangan pada perusahaan perbankan. Seperti misalnya Gadioux (2011) yang menguji pengaruh CSR terhadap kinerja keuangan pada 127 bank-bank berskala internasional antara tahun 2002 sampai dengan 2008 dan menemukan bahwa bahwa terdapat pengaruh positif antara kedua variabel tersebut. Weshah, Dahiyat, Abu Awwad, \& Hajjat (2012) juga membuktikan bahwa CSR berpengaruh positif terhadap kinerja keuangan perusahaan perbankan yang terdaftar di Pasar Modal Yordania. Ahmed, Islam, \& Hasan (2012) meneliti sektor perbankan di Bangladesh dan menemukan bahwa rata-rata ROA perusahaan yang memiliki corporate social performance tinggi lebih tinggi daripada rata-rata ROA perusahaan yang memiliki corporate social performance rendah. Cornett, Erhemjamts, \& Tehranian (2014) menemukan bahwa terdapat pengaruh positif antara kinerja keuangan yang diukur dengan ROA dan ROE dengan skor CSR pada perusahaan perbankan komersial skala besar di Amerika Serikat. Dan Wu \& Shen (2013) membuktikan secara empiris bahwa CSR berpengaruh positif terhadap kinerja keuangan 162 perusahaan perbankan dari 22 negara.

Pengukuran variabel CSR yang berbeda dari penelitian-pernelitian terdahulu juga menjadi motivasi penelitian ini. Penelitian ini menggunakan pendekatan lain sebagai proksi CSR. Untuk dapat menilai seberapa jauh perusahaan perbankan memiliki komitmen untuk menerapkan CSR sebagai sustainability development merujuk pada karakteristik social bank, penelitian akan berfokus pada apakah aktivitas bisnis perusahaan perbankan memperhatikan nilai etika atau sosial. Karena jika suatu bank sungguh melaksanakan bisnis keuangan yang bertanggung jawab, tentunya akan terefleksi dalam akun-akun laporan keuangannya (Relaño, 2011), maka penelitian ini akan menilai dimensi-dimensi etika/sosial berdasarkan prinsip-prinsip social bank dalam laporan posisi keuangan perusahaan perbankan.

Berdasarkan uraian pada pendahuluan, penelitian ini ingin mengkaji secara empiris pengaruh Corporate Social Responsibility berbasis karakteristik social bank terhadap kinerja perusahaan perbankan di Bursa Efek Indonesia.

\section{KAJIAN TEORI}

Teori Tentang CSR. Beberapa teori yang mendasari munculnya CSR antara lain social control theory, agency theory, dan stakeholder theory. Teori-teori tersebut dijelaskan berikut ini.

Menurut Weshah, Dahiyat, Abu Awwad, \& Hajjat (2012), ide utama dari social contract theory adalah bagaimana menghubungkan suatu perusahaan dengan masyarakat. Menurut teori ini, bisnis harus beroperasi secara bertanggung jawab bukan hanya karena kepentingan komersial perusahaan harus seperti itu, namun karena ini merupakan bagian dari bagaimana sesungguhnya masyarakat secara implisit mengharapkan suatu bisnis beroperasi. Lebih jauh, menurut paradigma kontrak sosial, suatu bisnis adalah suatu institusi sosial dan seharusnya masuk dalam struktur sosial sebagai suatu keluarga, sistem 
pendidikan dan institusi religius, membantu meningkatkan kualitas hidup dan memenuhi kebutuhan masyarakat.

Agency theory menyatakan bahwa dalam suatu transaksi, salah satu pihak (prinsipal) menunjuk pihak lain (agen) untuk bertindak mengatasnamakan pihak tersebut. Dalam hal ini prinsipal harus memiliki kepercayaan terhadap agen walaupun dalam situasi ketidaklengkapan informasi dan ketidakpastian hasil. Friedman (1970) dalam Weshah, Dahiyat, Abu Awwad, \& Hajjat (2012) menggambarkan agency theory dalam kritikannya terhadap CSR, menjelaskan bahwa manajer, sebagai agen untuk pemilik perusahaan, memiliki tanggung jawab untuk memaksimalkan laba perusahaan; mengeluarkan uang untuk kegiatan selain untuk tujuan tersebut merupakan penyalahgunaan tanggung jawab. Namun Carroll (1979) dalam Weshah, Dahiyat, Abu Awwad, \& Hajjat (2012) menunjukkan bahwa kepentingan ekonomi dan sosial perusahaan adalah saling berkaitan. Contohnya, produk yang aman adalah menjadi perhatian keduanya, baik sisi ekonomi maupun sisi sosial. Oleh karena itu, praktik CSR juga merupakan kepentingan ekonomi yang penting bagi perusahaan.

Sementara sebelumnya perhatian hanya aktivitas perusahaan yang berdampak secara nyata terhadap pemegang saham, Freeman dan Reed (1983) dalam Foote, Gaffney, \& Evans, (2010) mengembangkan teori bahwa ada grup-grup lain yang perlu diperhatikan sama baiknya, antara lain pekerja, pelanggan, dan masyarakat. Grup-grup selain pemegang saham sangat berkepentingan dengan setiap tindakan perusahaan. Pemegang saham dan grup-grup selain pemegang saham disebut sebagai stakeholder. Stakeholders sangat mempengaruhi keberhasilan perusahaan. Manajer hanya akan yakin dapat mencapai tujuan perusahaannya ketika mereka berhasil membangun hubungan baik dengan stakeholders (Duke II \& Kankpang, 2013). Stakeholder theory dapat menjelaskan pengaruh CSR dan kinerja perusahaan. Stakeholders memiliki kekuatan untuk mempengaruhi citra perusahaan. Ketika perusahaan melakukan oparasi bisnis yang tidak bertanggung jawab terhadap sosial dan lingkungan, stakeholders akan membangun penilaian yang tidak baik terhadap perusahaan tersebut dan ini akan berdampak langsung pada kinerja keuangan perusahaan.

Social Bank. Social bank merupakan institusi keuangan baru yang meyakini bahwa profitabilitas semestinya tidak hanya diukur dari pengembalian keuangan tapi juga dari manfaat sosial (Relaño, 2011). Pandangan inilah yang membedakan social bank dengan institusi perbankan umumnya. Hal inilah yang membuat institusi keuangan ini disebut social bank atau ethical bank. Untuk jenis institusi keuangan baru ini maksimalkan keuntungan bukan merupakan satu-satunya tujuan yang ingin dicapai melalui aktivitas bisnisnya, namun nilai tambah pada sosial dan lingkungan juga menjadi tujuan yang ingin dicapai (Relaño, 2011). Maka berbeda dari institusi perbankan umumnya, social bank menyeimbangkan profitabilitas dan etika. Dengan kata lain, social bank mengintegrasikan nilai etika kedalam semua proyek keuangannya.

Social bank merupakan institusi perbankan yang melakukan CSR dengan berkomitmen pada pembangunan berkelanjutan (sustainable development) bukan hanya sekedar strategi pemasaran. Nilai etika/CSR merupakan suatu bagian integral dari keseluruhan aktivitas bisnisnya. Berbeda dengan institusi perbankan umumnya memanfaatkan nilai etika/CSR hanya sebagai aksesoris untuk menarik klien baru dan memaksimalkan keuntungan. Social bank siap memilih untuk beroperasi dengan profit 
margin yang kecil asalkan hal ini akan memberikan nilai tambah pada sosial dan lingkungan.

Social Bank dan Sustainability Development. Relaño (2011) mengkarakteristikan social bank ke dalam dua dimensi yaitu dimensi eksternal dan internal. Dimensi eksternal terkait dengan aktivitas finansial yang dilakukan sedangkan dimensi internal terkait dengan fungsi dari institusi.

Dilihat dari dimensi eksternal, social bank biasanya dikategorikan sebagai berikut:

1. Social bank biasanya menolak untuk berpartisipasi dalam kegiatan-kegiatan spekulasi di pasar modal. Mereka menganggap bahwa aktivitas ini yang menyebabkan terjadinya banyak krisis internasional, kesenjangan sosial, masalah lingkungan, dan lain sebagainya. Socal bank memang secara terbatas menjual SRI, namun ini merupakan permintaan klien, atau memegang sampai jatuh tempo beberapa produk finansial untuk tujuan mengantisipasi potensi kebutuhan likuiditas. Tapi tidak sama dengan bank umum lainnya, partisipasi social bank dalam pasar modal secara umum tidak singnifikan, karena ini bukan merupakan aktivitas bisnis utamanya. Dan kalaupun terlibat dalam aktivitas pasar modal, hal ini dipastikan untuk investasi jangka panjang dan bukan merupakan aktivitas spekulasi.

2. Terkait dengan poin diatas, maka aktivitas utama dari institusi keuangan baru ini adalah berfokus pada bisnis origin suatu bank yaitu mengumpulkan tabungan dan mendistribusikan pinjaman.

3. Social bank memberikan keutamaan pada dimensi sosial, etika atau lingkungan dalam setiap proyek keuangan mereka. Hal ini berbeda dengan bank umumnya, yang berpraktik hanya pada satu prinsip yaitu fokus pada kinerja keuangan, social bank menempatkan tiga prinsip yaitu kinerja lingkungan, sosial, dan keuangan. Perhatian khusus sosial bank adalah pada bidang perumahan ramah lingkungan dan sosial, pertanian organik, pengembangan energi alternatif, UMKM, dan lain-lain.

4. Mempererat solidaritas antar penabung dan peminjam untuk memungkinkan kesepakatan pinjaman dengan bunga yang rendah (bahkan lebih rendah dari tarif bunga yang berlaku) bagi proyek-proyek yang berorientasi sosial, etika, dan lingkungan.

5. Jangkauan social bank hanya bersifat lokal atau regional saja. Nasbah social bank terbatas hanya dalam lingkup lokal atau regional saja. Hal ini dikarenakan social bank lebih berisiko dibanding dengan bank umum lainnya maka social bank perlu mengenal dan memahami dengan baik wilayah dimana mereka beroperasi dan klien-klien yang mereka danai. Dengan jangkauan yang lebih dekat akan memudahkan social bank melakukan hal tersebut. berikut:

Sedangkan dilihat dari dimensi internal, social bank memiliki karakteristik sebagi

1. Karena biaya operasional social bank lebih tinggi dari bank pada umumnya, mereka cenderung memiliki kantor yang kecil dan sebagian besar beroperasi melalui telepon, internet atau email.

2. Transparansi. Social bank memberikan perhatian khusus pada penyajian informasi rinci terkait aktivitasnya. Berbeda dengan bank pada umumnya, social bank transparan terhadap informasi tentang siapa yang menerima dan berapa besar pinjaman yang diberikan. 
3. Pertisipasi dan demokrasi. Hampir semua social bank berstatus hukum bank koperasi/mutual. Hal ini memungkinkan keputusan dibuat secara demokratis, karena setiap anggota memiliki hak suara tanpa melihat besarnya investasi yang ditanamkan. Oleh karena orang-orang lebih penting daripada modal dalam proses pengambilan keputusan maka inilah alasan kenapa institusi perbankan ini disebut social bank.

Adanya usaha mengarah pada kesetaraan disetiap level juga merupakan karakteristik social bank. Prinsip ini tidak hanya diterapkan hanya pada kesetaraan gender, tapi juga pada hal-hal lain seperti misalnya kebijakan penggajian.

Corporate Social Responsibility (CSR) dan Kinerja Perusahaan. Stakeholder theory dapat menjelaskan pengaruh CSR dan kinerja perusahaan (Lako, 2011). Stakeholders memiliki kekuatan untuk mempengaruhi citra perusahaan. Perusahaan yang mampu memenuhi ekspektasi berbagai macam stakeholders perusahaan maka mereka akan lebih mampu untuk menghasilkan kinerja perusahaan yang baik. Dukungan sikap stakeholders terhadap perusahaan akan sangat dipengaruhi oleh seberapa jauh ekspektasi mereka terpenuhi oleh perusahaan dan hal ini sangat berpengaruh pada kinerja perusahaan khususnya kinerja saham pada perusahaan publik. Ketika perusahaan melakukan operasi bisnis yang tidak bertanggung jawab terhadap sosial dan lingkungan, stakeholders akan membangun penilaian yang tidak baik terhadap perusahaan tersebut dan ini akan berdampak langsung pada kinerja keuangan perusahaan. Oleh sebab itu CSR merupakan alat yang digunakan perusahaan untuk dapat mengakomodasi ekspektasi stakeholders. CSR dapat mempengaruhi opini masyarakat terhadap perusahaan terkait dengan tanggung jawab mereka pada lingkungan dan sosial. Penelitian-penelitian terdahulu (Arshad, Mansor, \& Othman (2012), Wang, Qiu, \& Kong (2011), Wang, Y (2011) dan Saleh et al. (2011)) telah menjelaskan bahwa CSR berpengaruh terhadap kinerja keuangan perusahaan.

Hipotesis. Berdasarkan penalaran tersebut maka dibangun hipotesis sebagai berikut:

$\mathrm{Ha}_{1}$ : CSR berbasis karakteristik social bank berpengaruh secara signifikan terhadap kinerja perusahaan perbankan yang terdaftar di BEI

\section{METODE}

Populasi dan Sampel. Populasi penelitian ini adalah perusahaan perbankan yang terdaftar di Bursa Efek Indonesia (BEI). Sampel penelitian ini adalah perusahaan perbankan yang terdaftar dan tidak delisting di BEI antara tahun 2008 sampai dengan 2012.

Definisi Operasional dan Pengukuran Variabel. Variabel dependen dalam penelitian ini adalah kinerja perusahaan. Kinerja perusahaan dalam hal ini didefinisikan sebagai besarnya perbandingan nilai perusahaan dengan nilai buku total asetnya. Kinerja perusahaan ini diproksikan dengan Tobin's Q. Penelitian ini menggunakan persamaan Tobin's Q yang dikembangkan Chung \& Pruitt (1994) yaitu Q = (MVE + PS + DEBT) / TA. Dalam hal ini MVE (market value equity) adalah hasil perkalian harga saham penutupan dengan jumlah saham yang beredar. PS (preferred shares) adalah nilai pari atau nominal sahan preferen yang beredar. DEBT adalah nilai liabilitas jangka pendek. TA (total asset) adalah total aset perusahaan. Data kinerja perusahaan dihitung dari laporan keuangan tahun 2012 saja. Alasan utama menggunakan Tobin's Q dari pada pengukuran kinerja keuangan yang lain adalah bahwa Tobin's Q tidak hanya mengukur kinerja masa lalu perusahaan seperti ROA dan ROE, tapi juga merepresentasikan nilai perusahaan yang 
termasuk didalamnya prospek perusahaan di masa yang akan datang (Lee, Seo, \& Sharma, 2013).

Variabel independen penelitian ini adalah CSR. CSR dalam penelitian ini adalah sejauh mana perusahaan perbankan berkomitmen pada sustainability development melalui CSR dalam aktivitas bisnis utamanya. Pengukuran CSR dalam penelitian ini akan berbasis pada karakteristik social bank. Peneliti sepakat dengan Relaño (2011) bahwa untuk menilai sejauh mana perusahaan perbankan berkomitmen pada sustainability development melalui CSR, fokus riset tidak pada apa yang perusahaan perbankan "ucapkan” namun pada apa yang perusahaan perbankan "sesungguhnya lakukan”. Artinya riset tidak melihat pada pernyataan-pernyaataan terkait aktivitas CSR baik di annual report ataupun sustainability report. Jika bank sungguh melakukan kegiatan bisnis keuangan yang bertanggungjawab maka akan terefleksi dalam akun-akun laporan keuangan. Dalam penelitian ini, menilai dimensi etika dan sosial (social bank) dengan melihat akun-akun dalam laporan posisi keuangan. Berikut tahapan-tahapan teknik analisis data dalam riset ini:

1. Peneliti mengelompokkan akun-akun dalam laporan posisi keuangan baik aset pada sisi debet maupun liabilitas dan ekuitas pada sisi kredit ke dalam "transaksi klien” dan "transaksi keuangan”. Transaksi klien di sisi aset adalah kredit atau pinjaman yang diberikan bank kepada kliennya. Transaksi klien di sisi liabilitas adalah simpanansimpanan nasabah. Transaksi keuangan di sisi aset adalah penempatan pada BI dan bank lain, aset keuangan yang diperdagangkan, investasi keuangan, penyertaan saham, surat-surat berharga, surat-surat berharga yang dibeli dengan janji dijual kembali, surat-surat berharga yang dimiliki hingga jatuh tempo, efek-efek untuk tujuan investasi, wesel ekspor, obligasi pemerintah, aset derivatif/ tagihan derivatif, investasi pemegang polis pada kontrak unit-linked, investasi sewa pembiayaan, dan tagihan akspetasi. Transaksi keuangan di sisi liabilitas adalah kewajiban derivatif, surat-surat berharga yang diterbitkan, obligasi yang diterbitkan, obligasi konversi, kewajiban akseptasi, kewajiban kepada pemegang polis unit-linked, efek utang yang diterbitkan, efek yang dijual dengan janji dibeli kembali.

2. Kemudian peneliti membuat persentase besarnya transaksi klien (simpanan dan pinjaman nasabah) dan transaksi keuangan terhadap total aset di sisi debet atau total liabilitas ditambah ekutias di sisi kredit.

3. Selanjutnya peneliti membandingkan persentase besarnya: (a) Pinjaman nasabah (aset) dengan simpanan nasabah (liabilitas), (b) Pinjaman nasabah (aset) dengan transaksi keuangan (aset), dan (c) Simpanan nasabah (liabilitas) dengan transaksi keuangan (liabilitas)

Merujuk pada karakteristik/prinsip social bank, pembandingan tersebut bertujuan untuk melihat aktivitas bisnis bank apakah lebih dominan pada aktivitas original perbankan (mengumpulkan tabungan dan mendistribusikan pinjaman) atau pada aktivitas transasksi keuangan/spekulasi. Bank dianggap sebagai sosial bank jika memiliki ciri-ciri sebagai berikut: (a) Persentase pinjaman nasabah (aset) sama atau lebih kecil dari persentase simpanan nasabah (liabilitas), (b) Persentase transaksi keuangan (aset) lebih kecil dari persentase pinjaman nasabah (aset), (c) Persentase transaksi keuangan (liabilitas) lebih kecil dari persentase simpanan nasabah (liabilitas)

4. Untuk perusahaan perbankan yang selama periode pengamatan (2008 - 2012) yang berturut-turut memiliki karakteristik social bank akan diberi kode 1 dan kode 0 untuk sebaliknya. 
Dalam penelitian ini juga digunakan variabel kontrol. Variabel kontrol yang digunakan adalah ukuran perusahaan. Ukuran perusahaan didefinisikan sebagai besar kecilnya suatu perusahaan yang ditentukan dari total aset yang dimiliki. Ukuran perusahaan diukur dengan Ln aktiva tetap. Ukuran perusahaan merupakan variabel yang penting karena banyak hasil penelitian menjelaskan bahwa perusahaan yang kecil kurang berkomitmen dengan CSR dibandingkan dengan perusahaan besar (Hettiarachchi \& Gunawardana, 2012).

Teknik Analisis. Sebelum melakukan uji hipotesis perlu dilakukan pengujian asumsi klasik yang tujuannya untuk memastikan bahwa model penelitian bersifat BLUE (best liniear unbiased estimator) (Kuncoro, 2009). Pengujian yang akan dilakukan untuk model penelitian ini adalah uji normalitas galat/error, multikolinieritas, dan heterokedastisitas. Pengujian hipotesis dalam penelitian ini menggunakan model regresi berganda. Peneliti akan menggunakan software $\mathrm{R}$ untuk teknik pengujian hipotesis. Tingkat signifikasi ditetapkan $5 \%$.

\section{HASIL DAN PEMBAHASAN}

Populasi penelitian ini adalah perusahaan-perusahaan perbankan yang terdaftar di Bursa Efek Indonesia (BEI). Sampel penelitian ini adalah perusahaan-perusahaan perbankan yang konsisten terdaftar di BEI dalam tahun 2008 sampai dengan 2012. Terdapat sebanyak 31 perusahaan perbankan yang terdaftar antara tahun 2008 sampai dengan 2012, namun hanya 29 perusahaan perbankan yang secara konsisten terdaftar dalam tahun 2008 sampai dengan 2012. Dua perusahaan perbakan yang tidak diambil sebagai sampel adalah Bank Jabar Banten Tbk. dan Bank Sinar Mas Tbk. karena baru terdaftar pada tahun 2010. Untuk memenuhi asumsi klasik model, peneliti menggunakan trimming method atau membuang data outlier dari sampel ((Jogiyanto, 2014) dan sebanyak lima perusahaan perbankan dikeluarkan dari sampel karena outlier. Kelima perusahaan tersebut adalah Bank Tabungan Negara (Persero), Bank Mayapada International Tbk, Bank Swadesi Tbk, Bank Kesawan Tbk, dan Bank Tabungan Pesiunan Nasional Tbk. Sehingga jumlah sampel yang digunakan dalam penelitian ini sebanyak 24 perusahaan perbankan. Sampel perusahaan tersaji pada tabel 1 .

Tabel 1. Perusahaan-perusahaan Perbankan yang Menjadi Sampel

\begin{tabular}{ccl}
\hline No & Kode & \multicolumn{1}{c}{ Nama } \\
\hline 1 & AGRO & Bank Agroniaga Tbk \\
2 & BABP & Bank ICB Bumi Putra Tbk \\
3 & BACA & Bank Capital Indonesia Tbk \\
4 & BAEK & Bank Ekonomi Raharja Tbk \\
5 & BBCA & Bank Central Asia Tbk \\
6 & BBKP & Bank Bukopin Tbk \\
7 & BBNI & Bank Negara Indonesia (Persero) Tbk \\
8 & BBNP & Bank Nusantara Parahyangan Tbk \\
9 & BBRI & Bank Rakyat Indonesia (Persero) Tbk \\
10 & BCIC & Bank Mutiara Tbk \\
\hline
\end{tabular}




\begin{tabular}{lcl}
\multicolumn{3}{l}{ Lanjutan Tabel 1. } \\
\hline 11 & DMN & Bank Danamon Indonesia Tbk \\
12 & BEKS & Bank Pundi Indonesia Tbk \\
13 & BMRI & Bank Mandiri (Persero) Tbk \\
14 & BNBA & Bank Bumi arta Tbk \\
15 & BNGA & Bank CIMB Niaga Tbk \\
16 & BNII & Bank Internasional Indonesia Tbk \\
17 & BNLI & Bank Permata Tbk \\
18 & BVIC & Bank Victoria International Tbk \\
19 & INPC & Bank Artha Graha International Tbk \\
20 & MCOR & Bank Windu Kentjana International Tbk \\
21 & MEGA & Bank Mega Tbk \\
22 & NISP & Bank NISP OCBC Tbk \\
23 & PNBN & Bank Pan Indonesia Tbk \\
24 & SDRA & Bank Himpunan Saudara 1906 Tbk \\
\hline
\end{tabular}

Statistik Deskriptif. Ukuran perusahaan perbankan yang menjadi sampel cukup beragam dengan rentang yang cukup besar dilihat dari total aset. Hal ini dapat dilihat pada tabel 2, yang menyajikan bahwa rata-rata total aset 127.042.671.759.369 dengan nilai kuartil I 7.667.530.750.000 dan kuartil III 150.542.288.250.000 sedangkan total aset minimal 3.483.516.588.857 (Bank Bumi arta Tbk) dan total aset maksimum 635.618.708.000.000 (Bank Mandiri (Persero) Tbk).

Kinerja perusahaan relatif baik dilihat dari proksi rasio Tobin's Q. Pada tabel 2 disajikan bahwa rata-rata nilai Tobin's Q 1,053935561 dengan kuartil I 0,994994763, kuartil III 1,094641413, nilai minimum 0,950941378 (Bank Victoria International Tbk), dan nilai maksimum 1,381923795 (Bank Central Asia Tbk). Rata-rata 1,053935561 lebih besar dari satu menunjukkan bahwa nilai pasar perusahaan melebihi nilai bukunya.

Tabel 2. Ringkasan Numerikal Variabel Ukuran dan Kinerja Perusahaan

\begin{tabular}{lrr}
\hline & Ukuran Perusahaan (Total Aset) & Kinerja Perusahaan (Tobin's Q) \\
\hline Rata-rata & 127.042 .671 .759 .369 & 1,053935561 \\
Deviasi Standar & 181.873 .989 .060 .090 & 0,096147377 \\
Nilai Minimum & 3.483 .516 .588 .857 & 0,950941378 \\
Kuartil I (25\%) & 7.667 .530 .750 .000 & 0,994994763 \\
Kuartil III (75\%) & 150.542 .288 .250 .000 & 1,094641413 \\
Nilai Maksimum & 635.618 .708 .000 .000 & 1,381923795 \\
\hline
\end{tabular}

Tabel 3. Distribusi FrekuensiVariabel CSR

\begin{tabular}{lcc}
\hline & Jumlah & Persentase \\
\hline CSR & 15 & $62.5 \%$ \\
Non CSR & 9 & $37.5 \%$ \\
Total (n) & 24 & $100 \%$ \\
Chi-squared test & \multicolumn{3}{c}{} \\
p-value & 0,2207 \\
Simpulan & Goodness of fit variabel dummy memadai \\
\hline
\end{tabular}


Tabel 3 menyajikan distribusi frekuensi variabel CSR, dalam hal ini 62,5\% atau 15 perusahaan perbankan yang menjadi sampel menerapkan CSR yang sesuai dengan karakteristik social bank atau perusahaan perbankan tersebut melaksanakan CSR berorientasi pada sustainability finance. Sedangkan sisanya 37\% atau 9 perusahaan perbankan yang menjadi sampel penelitian belum menyelenggarakan CSR yang sesuai dengan karakteristik social bank. Dengan demikian sebagaian besar perusahaan perbankan yang terdaftar di BEI yang menjadi sampel penelitian telah menerapkan CSR yang berorientasi pada sustainability finance. Peneliti juga menguji goodness of fit variabel CSR, dan hasilnya menunjukkan bahwa variabel CSR yang merupakan variabel dummy memiliki goodness of fit yang memadai pada probabilitas 50:50.

Pada tabel 4 digambarkan 15 perusahaan yang selama tahun 2008 s.d 2012 konsisten memenuhi karakteristik social bank dan 9 perusahaan yang tidak secara konsisten selama 2008 s.d. 2012 tidak secara konsisten memenuhi karakteristik social bank.

Tabel 4. CSR Perusahaan Perbankan Berbasis Social Bank selama tahun 2008 s.d 2012 (Tanda warna abu-abu menunjukkan tidak sesuai kriteria Social Bank)

\begin{tabular}{|c|c|c|c|c|c|c|c|c|c|c|c|c|}
\hline \multirow{3}{*}{ NO } & \multirow{3}{*}{ KODE } & \multirow{3}{*}{ NAMA } & \multicolumn{10}{|c|}{ TAHUN } \\
\hline & & & \multirow{2}{*}{\multicolumn{2}{|c|}{$\begin{array}{r}2008 \\
\mathrm{~L}>\mathrm{DFT}>\end{array}$}} & \multirow{2}{*}{\multicolumn{2}{|c|}{$\begin{array}{r}2009 \\
\mathrm{~L}>\mathrm{DFT}\end{array}$}} & \multirow{2}{*}{\multicolumn{2}{|c|}{$\begin{array}{c}2010 \\
\mathrm{~L}>\mathrm{D} \quad \mathrm{FT}>\end{array}$}} & \multicolumn{2}{|c|}{2011} & \multicolumn{2}{|c|}{2012} \\
\hline & & & & & & & & & $\mathrm{L}>\mathrm{I}$ & FT & $\mathrm{L} L>1$ & $\mathrm{FT}>\mathrm{L}$ \\
\hline 1 & AGRO & 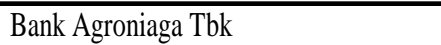 & & & & & & & & & & \\
\hline 2 & BABP & Bank ICB Bumi Putra Tbk & & & & & & & & & & \\
\hline 3 & BACA & Bank Capital Indonesia Tbk & & & & & & & & & & \\
\hline 4 & BAEK & Bank Ekonomi Raharja Tbk & & & & & & & & & & \\
\hline 5 & BBCA & Bank Central Asia Tbk & & & & & & & & & & \\
\hline 6 & BВKP & Bank Bukopin Tbk & & & & & & & & & & \\
\hline 7 & BBNI & Bank Negara Indonesia (Persero) Tbk & & & & & & & & & & \\
\hline 8 & BBNP & Bank Nusantara Parahyangan Tbk & & & & & & & & & & \\
\hline 9 & BBRI & Bank Rakyat Indonesia (Persero) Tbk & & & & & & & & & & \\
\hline 10 & BCIC & Bank Mutiara Tbk & & & & & & & & & & \\
\hline 11 & BDMN & Bank Danamon Indonesia Tbk & & & & & & & & & & \\
\hline 12 & BEKS & Bank Pundi Indonesia Tbk & & & & & & & & & & \\
\hline 13 & BMRI & Bank Mandiri (Persero) Tbk & & & & & & & & & & \\
\hline 14 & BNBA & Bank Bumi arta Tbk & & & & & & & & & & \\
\hline 15 & BNGA & Bank CIMB Niaga Tbk & & & & & & & & & & \\
\hline 16 & BNII & Bank Internasional Indonesia Tbk & & & & & & & & & & \\
\hline 17 & BNLI & Bank Permata Tbk & & & & & & & & & & \\
\hline 18 & BVIC & Bank Victoria International Tbk & & & & & & & & & & \\
\hline 19 & INPC & Bank Artha Graha International Tbk & & & & & & & & & & \\
\hline 20 & MCOR & Bank Windu Kentjana International Tbk & & & & & & & & & & \\
\hline 21 & MEGA & Bank Mega Tbk & & & & & & & & & & \\
\hline 22 & NISP & Bank NISP OCBC Tbk & & & & & & & & & & \\
\hline 23 & PNBN & Bank Pan Indonesia Tbk & & & & & & & & & & \\
\hline 24 & SDRA & Bank Himpunan Saudara 1906 Tbk & & & & & & & & & & \\
\hline \multirow{2}{*}{\multicolumn{3}{|c|}{ Jumlah }} & 2 & 2 & 0 & 5 & 2 & 3 & 2 & 1 & 1 & 1 \\
\hline & & & & 4 & & 5 & & & & 3 & & 2 \\
\hline
\end{tabular}

Keterangan:

L : Loan (Client Transactions - Aset)

D : Deposits (client Transactioans - Liabilitas)

FT : Financial Transactions - Aset 
Uji Hipotesis. Dalam penelitian ini, untuk menjawab pertanyaan penelitian dibangunlah sebuah hipotesis yaitu CSR berbasis karakteristik social bank berpengaruh secara signifikan terhadap kinerja perusahaan perbankan yang terdaftar di BEI yang akan diuji secara empiris dalam penelitian ini. Pengujian hipotesis menggunakan model regresi berganda dan aplikasi statistik R dipakai untuk pengolahan data.

Tabel 5 menunjukkan bahwa p-value nilai t variabel CSR adalah 0,029918 lebih kecil dari 0,05. Dengan demikian hipotesis alternatif yaitu CSR berbasis karakteristik social bank berpengaruh secara signifikan terhadap kinerja perusahaan perbankan yang terdaftar di BEI terdukung dalam penelitian ini.

Tabel 5. Hasil Uji Hipotesis

\begin{tabular}{llll}
\hline Variabel Independen & Estimate/ $\beta$ & $\mathrm{t}$ & $\mathrm{p}$-value \\
\hline Intercept & $-0,058841$ & $-0,201$ & 0,842682 \\
CSR & -0.075769 & $-2,329$ & $0,029918^{*}$ \\
Ukuran Perusahaan & 0,037046 & 3,907 & $0,000811^{*}$ \\
\hline
\end{tabular}

*Signifikan pada level 5\%

Tabel 6. Goodness of Fit Model

\begin{tabular}{|c|c|c|}
\hline & $\mathrm{F}$ & p-value \\
\hline Uji F & 8,588 & $0,001881^{*}$ \\
\hline Adjusted $\mathrm{R}^{2}$ & & \\
\hline
\end{tabular}

*Signifikan pada level 5\%

Pada tabel 6 disajikan hasil uji $\mathrm{F}$ dan Adjusted $\mathrm{R}^{2}$, yang dalam hal ini merupakan indikator yang digunakan untuk menilai goodness of fit model penelitian. Dalam penelitian ini $p$ value nilai $\mathrm{F}$ adalah 0,001881 lebih kecil dari 0,05 yang artinya model estimasian mendekati atau sama dengan model rillnya. Adjusted $\mathrm{R}^{2}$ adalah 0,3975 (39,75\%) yang artinya 39,75\% variansi kinerja perusahaan bisa dijelaskan variabel CSR dan ukuran perusahaan. Dengan demikian goodness of fit model penelitian ini memadai.

\section{PEMBAHASAN}

Hasil penelitian menunjukkan bahwa secara empiris hipotesisi yang dibangun yaitu Corporate Social Responsibility (CSR) berpengaruh terhadap kinerja perusahaanperusahaan perbankan yang terdaftar di Bursa Efek Indonesia ditemukan terdukung pada level signifikan 5\%. Namun koefisien pengaruh CSR terhadap kinerja perusahaan adalah 0.075769, dengan demikian dapat dinyatakan bahwa dalam penelitian ini CSR yang diukur dengan pendekatan karakteristik social bank sebagai proksi sustainability development berpengaruh negatif secara signifikan terhadap kinerja perusahaan yang diukur dengan Tobin's Q. Atau dengan kata lain dapat dinyatakan bahwa CSR yang berbasis sustainability development tidak mempengaruhi peningkatan kinerja perusahaan perbankan yang terdaftar di BEI. Hasil penelitian ini bertolak belakang dengan teori-teori dan penelitian-penelitian sebelumnya yang mendukung bahwa praktik CSR akan meningkatkan kinerja perusahaan.

Secara empiris CSR yang berbasis sustainability development tidak mempengaruhi peningkatan kinerja perusahaan perbankan yang terdaftar di BEI diduga karena masih 
rendahnya sensitivitas stakeholders terhadap isu CSR di pasar modal negera-negara berkembang. Penelitian-penelitian terdahulu tentang pengaruh CSR terhadap kinerja perusahaan sebagian besar berfokus pada pasar modal yang telah mapan, yang dalam hal ini sensistivitas stakeholders terhadap CSR sangat kuat sehingga perusahaan-perusahaan didesak tidak hanya beroperasi secara menguntungkan secara finansial namun harus beroperasi secara ramah lingkungan dan sosial. Sedangkan pada pasar modal yang sedang berkembang, sensitivitas stakeholders terhadap isu CSR masih rendah. Sebagai contoh misalnya hasil penelitian Crisóstomo, Freire, \& Vasconcellos (2011) yang membuktikan pada bursa efek yang masih berkembang, praktik CSR tidak mempengaruhi peningkatan kinerja keuangan perusahaan-perusahaan yang terdaftar di bursa efek tersebut. Sehingga tekanan stakeholders terhadap perusahaan untuk melaksanakan praktik CSR masih rendah. Apalagi untuk perusahaan perbankan yang kegiatan bisnisnya tidak secara langsung berdampak kepada perusakan kualitas lingkungan dan sosial. Sehingga praktik CSR tidak menjadi sorotan utama stakeholders hingga menyebabkan kinerja perusahaan perbankan menjadi terpengaruhi.

Penelitian ini menemukan bahwa arah pengaruh CSR terhadap kinerja perusahaan adalah negatif, yang artinya bahwa secara empiris praktik CSR malah menurunkan kinerja perusahaan. Penelitian ini menggunakan karakteristik social bank sebagai pendekatan dalam menilai apakah perusahaan perbankan melaksanakan CSR atau tidak. Social bank dikenal sebagai perusahaan perbankan yang menerapkan sustainability finance. Sustainability finance artinya social bank menolak untuk berpartisipasi dalam proyekproyek keuangan yang bersifat spekulatif sehingga proses bisnisnya berfokus pada peran utama bank yaitu mengumpulkan tabungan dari nasabah dan mendistribusikannya melalui pinjaman. Dalam penelitian ini, 62,5\% sampel merupakan perusahaan perbankan yang memenuhi kriteria sosial bank. Dengan ikut menerapkan praktik CSR berbasis sustainability financial, secara langsung berdampak pada berkurang atau hilangnya pendapatan perusahaan-perusahaan perbankan karena adanya pembatasan-pembatasan proyek-proyek keuangan. Secara otomatis hal ini tentunya akan ikut menurunkan kinerja keuangan perusahaan perbankan. Sedangkan pada bursa efek di negara-negara berkembang seperti BEI, kinerja keuangan perusahaan merupakan fokus perhatian utama dari pemegang saham dan kreditur.

Lebih jauh menganalisis bahwa 62,5\% perusahaan perbankan yang terdaftar di BEI memiliki karakteristik social bank, diperoleh suatu gambaran yang jelas bahwa mayoritas perusahaan perbankan yang terdaftar di BEI telah memiliki komitmen terhadap sustainability developement melalui proses bisnis yang mencerminkan sustainability financial. Dalam perspektif social bank, ukuran keberhasilan penerapan CSR bukan pada kinerja keuangan perusahaan semata, namun lebih dari itu yaitu memberikan nilai tambah pada lingkungan dan sosial. Karena prinsip social bank yaitu "less profit, more sense" yang artinya mereka bersedia beroperasi dengan mendapatkan profit margin yang sempit namun dibalik itu memberikan manfaat yang lebih besar pada lingkungan dan sosial. Pada bursa efek yang masih berkembang seperti BEI, karakteristik perusahaan perbankan seperti ini tentunya tidak diminati oleh pemegang saham atau investor yang lebih menyukai keuntungan jangka pendek. Analisis ini semakin menjelaskan hasil penelitian ini bahwa CSR berbasis karakteristik social bank berpengaruh negatif signifikan pada kinerja perusahaan yang dalam hal ini diukur dengan Tobin's Q yang merupakan salah satu ukuran kinerja keuangan perusahaan. 


\section{PENUTUP}

Simpulan. Tujuan penelitian ini adalah untuk menguji secara empiris pengaruh Corporate Social Responsibility berbasis karakteristik social bank terhadap kinerja perusahaan perbankan di Bursa Efek Indonesia. Dengan mengambil sampel perusahaan perbankan yang terdaftar di BEI secara berturut-turut sejak tahun 2008 sampai dengan 2012, ditemukan bahwa 62,5\% sampel memenuhi karakteristik social bank yaitu persentase pinjaman nasabah (aset) sama atau lebih kecil dari persentase simpanan nasabah (liabilitas), persentase transaksi keuangan (aset) lebih kecil dari persentase pinjaman nasabah (aset), persentase transaksi keuangan (liabilitas) lebih kecil dari persentase simpanan nasabah (liabilitas) secara konsisten antara tahun 2008 sampai dengan 2012. Sebanyak 62,5\% inilah dinyatakan sebagai perusahaan perbankan yang menerapkan CSR berbasis sustainability development. Kinerja perusahaan dalam penelitian ini diukur menggunakan Tobins' Q. Hasil pengujian hipotesis pada tingkat signifikan 5\%, menunjukkan bahwa Corporate Social Responsibility berbasis karakteristik social bank berpengaruh signifikan terhadap kinerja perusahaan perbankan di Bursa Efek Indonesia. Koefisien pengaruh CSR terhadap kinerja perusahaan adalah -0,075769, dengan demikian dapat dinyatakan bahwa dalam penelitian ini CSR yang diukur dengan pendekatan karakteristik social bank sebagai proksi sustainability development berpengaruh negatif secara signifikan terhadap kinerja perusahaan yang diukur dengan Tobin's Q. Atau dengan kata lain dapat dinyatakan bahwa CSR yang berbasis sustainability development tidak mempengaruhi peningkatan kinerja perusahaan perbankan yang terdaftar di BEI.

Saran. Penelitian selanjutnya sebaiknya terlebih dahulu melakukan penelitian lebih jauh terkait dengan tingkat sensitivitas stakeholders terhadap isu CSR pada BEI sebelum lebih jauh melakukan penelitian terkait dengan praktik CSR sebagai inisiatif kontribusi nyata pada sustainability development yang dikaitkan dengan kinerja perusahaan. Hal ini diperlukan supaya peneliti mendapatkan gambaran lebih jelas arah pengaruh CSR terhadap kinerja perusahaan.

Untuk mengeneralisasi hasil penelitian ini, peneliti selanjutnya perlu memperluas populasi penelitian tidak hanya pada perusahaan-perusahaan perbankan yang terdaftar di BEI tapi juga menambahkan perusahaan-perusahaan lain yang terdaftar di bursa efek pada negara-negara berkembang lainnya.

\section{DAFTAR PUSTAKA}

Ahmed, S. U., Islam, Z., \& Hasan, I. (2012) "Corporate Social Responsibility and Financial Performance Linkage: Evidence from the Banking Sector of Bangladesh". Journal of Organizational Management, 1 (1) hal. 14-21.

Arshad, R., Mansor, S. M., \& Othman, R. (2012) "Market Orientation, Firm Performance And The Mediating Effect Of Corporate Social Responsibility". The Journal of Applied Business Research, 28 (5) hal. 851-860.

Chen, H., \& Wang, X. (2011) "Corporate social responsibility and corporate financial performance in China: an empirical research from Chinese firms". Corporate Governance, 11(4), 361-370. doi:10.1108/14720701111159217

Chung, K. H., \& Pruitt, S. W. (1994) "A Simple Approximation of Tobin's q". Financial Management, 23 (3) hal. 70-74. 
Cornett, M. M., Erhemjamts, O., \& Tehranian, H. (2013) Corporate Social Responsibility and its Impact on Financial Performance: Investigation of U.S. Commercial Banks (pp. 1-53). Retrieved from http://ssrn.com/abstract=2333878

Crisóstomo, V. L., Freire, F. D. S., \& Vasconcellos, F. C. De. (2011) "Corporate social responsibility, firm value and financial performance in Brazil". Social Responsibility Journal, 7 (2) hal. 295-309. doi:10.1108/17471111111141549

Duke II, J., \& Kankpang, K. (2013) "Implications of Corporate Social Responsibility for the Performance of Nigerian Firms". Advance in Management \& Applied Economics, 3 (5) hal. 73-87.

Durbin, A., Herz, S., Hunter, D., \& Peck, J. (2006) Shaping The Future of Sustainable Finance: Moving from Paper Promises to Performance (pp. 1-98).

Foote, J., Gaffney, N., \& Evans, J. R. (2010) Corporate social responsibility : Implications for performance excellence. Total Quality Management, 21 (8), 799-812. doi:10.1080/14783363.2010.487660

Gadioux, S.-E. (2011) "The CSR Performance-Financial Performance Link in the Banking Industry: Evidence from International Panel Data". Responsible Organization Review, 6 (2) hal. 5-19.

Hettiarachchi, \& Gunawardana. (2012) "The Impact of Corporate Social Responsibility Reporting (CSRR) on Financial Performance - Empirical Evidence from Sri Lanka". The Business \& Management Review, 2 (1) hal. 66-77.

Jogiyanto. (2014) Metodologi Penelitian Bisnis: Salah Kaprah dan PengalamanPengalaman (Edisi 6.) Yogyakarta: BPFE.

Kuncoro, M. (2009) Metode Riset untuk Bisnis dan Ekomomi: Bagaimana Meneliti dan Menulis Tesis (Edisi 3.) Jakarta: Penerbit Erlangga.

Lako, A. (2011) Dekonstruksi CSR dan Reformasi Paradigma Bisnis dan Akuntansi. (S. Saat, Ed.) (p. 225). Penerbit Erlangga.

Lee, S., Seo, K., \& Sharma, A. (2013) Corporate social responsibility and firm performance in the airline industry: The moderating role of oil prices. Tourism Management, 38, 20-30. doi:10.1016/j.tourman.2013.02.002

Relaño, F. (2011) Maximizing social return in the banking sector. Corporate Governance, 11(3), 274-284. doi:10.1108/14720701111138698

Saleh, M., Zulkifli, N., \& Muhamad, R. (2011) "Looking for evidence of the relationship between corporate social responsibility and corporate financial performance in an emerging market". Asia-Pacific Journal of Business Administration, 3 (2) hal. 165190. doi:10.1108/17574321111169849

Walker, J. (2010) CSR bukan GREENWASH. Kompasiana. Retrieved January 08, 2013, from http://ekonomi.kompasiana.com/bisnis/2010/01/16/csr-bukan-greenwash54714.html

Wang, M., Qiu, C., \& Kong, D. (2011) "Corporate Social Responsibility, Investor Behaviors, and Stock Market Returns: Evidence from a Natural Experiment in China". Journal of Business Ethics, 101 (1) hal. 127-141. doi:10.1007/s10551-0100713-9

Wang, Y. (2011) Corporate Social Responsibility and Stock Performance - Evidence from Taiwan. Modern Economy, 2 (5) hal. 788-799.

Weshah, S. R., Dahiyat, A. A., Abu Awwad, M. R., \& Hajjat, E. S. (2012) "The Impact of Adopting Corporate Social Responsibility on Corporate Financial Performance: 
Evidence from Jordanian Banks". Interdisciplinary Journal of Contemporary Research in Business, 4 (5) hal. 34-44.

Wu, M., \& Shen, C. (2013) "Corporate Social Responsibility in the Banking Industry: Motives and Financial Performance". Journal of Banking and Finance, 37 (9) hal. 3529-3547. doi:10.1016/j.jbankfin.2013.04.023 